Dr hab. Piotr Mostowik, prof. UJ

DR Olga BOBRZYŃSKA ${ }^{1}$

Uniwersytet Jagielloński

\title{
O globalnych problemach na skutek wprowadzenia lokalnych fikcji prawnych powiązanych z tzw. macierzyństwem zastępczym (surrogate motherhood)
}

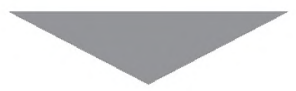

\section{Uwagi wstępne}

W ostatnich dekadach w niektórych systemach prawnych funkcjonuje i ewoluuje konstrukcja prawna określana jako macierzyństwo zastępcze (surrogate motherhood) $)^{2}$ bądź urodzenie zastępcze (surrogate birth) ${ }^{3}$. Jej wprowadzenie nastąpiło bezpośrednio, tj. w prawie materialnym, bądź pośrednio, tj. drogą uznawania skutków zagranicznych procedur (zastosowania obcego prawa lub uznania zagranicznej rejestracji stanu cywilnego). Konstrukcja ta, a za nią przedmiot

\footnotetext{
1 Tekst opracowania powstał na bazie referatu, przygotowanego $w$ ramach - wykonywanego w 2018 r. pod auspicjami Centrum Badań nad Rodziną UMK - projektu „Zagraniczne procedury tzw. urodzenia zastępczego w świetle uniwersalnego zakazu handlu dziećmi - ujęcie interdyscyplinarne".

2 Przykładami obecnej rzeczywistości popytu i podaży mogą być np. oferta ukraińskiego ośrodka: BioTexCom, [on-line:] http://biotexcom.com/information/brief-explanation-surrogacy-process 7 VIII 2019 izbiórka społeczna na nabycie dziecka w Republice Południowej Afryki przez parę holenderskich homoseksualistów: MZT, [on-line:] www.babyrainbow.nl-15VIII 2018.Zob. opracowania prawnoporównawcze zawarte w publikacjach zbiorowych Fundamental legal issues of surrogate motherhood. Global perspective, ed. P. Mos towik, Wydawnictwo Instytutu Wymiaru Sprawiedliwości, Warszawa 2019, oraz Fundamentalne problemy prawne surrogate motherhood. Perspektywa krajowa, red. P. Mostowik, Wydawnictwo Instytutu Wymiaru Sprawiedliwości, Warszawa 2019. 3 Tak P. Most owik, May you live in interesting times, [w:] i d em, Fundamental and legal issues of surrogate motherhood..., s. 12 .
} 
rozważań doktrynalnych, nie dotyczy - co mogłoby wynikać z dosłownego rozumienia tego pojęcia - subsydiarnej opieki nad dzieckiem sprawowanej zamiast jego matki (np. przez rodzinę zastępczą). Paradoksalnie obejmuje natomiast rozwiązania prawa osobowego, zobowiązań i rodzinnego (w tym o aktach stanu cywilnego) o skutku odwrotnym, tj. polegającym na nietraktowaniu w prawnym znaczeniu jako matki kobiety, która dziecko urodziła (matki biologicznej). Zamiast tego wprowadza się najczęściej fikcję prawną pochodzenia dziecka od innej kobiety, będącej stroną kontraktu, od której genetycznie dziecko przeważnie nie pochodzi (tj. często nie jest ona matką genetyczną). Niekiedy występuje dodatkowo fikcja prawna pochodzenia dziecka tylko od jednej osoby (bez możliwości następczego prawnego określenia drugiego z rodziców) bądź od dwóch osób tej samej płci. Takie specyficzne rozwiązania prowadzą m.in. do nabycia pierwotnego statusu (stanu cywilnego ${ }^{4}$ ) matki (bądź mężczyzny występującego w akcie urodzenia zamiast matki jako tzw. rodzic A) przez osobę, która dziecka in concreto nie urodziła, a nawet osobę, która in genere takiego statutu filiacyjnego w rozumieniu naturalnym (biologicznym) nabyć by nie mogła (np. przez samotną osobę lub drugiego mężczyznę) $)^{5}$.

Zasygnalizowane rozwiązania nie występują w większości systemów prawnych na świecie. Przeciwko nim przemawiają m.in. rozumienie godności człowieka (w szczególności kobiety) i tożsamości człowieka (w szczególności dziecka) oraz zasada nieprzenoszalności stanu cywilnego (pochodzenia dziecka) drogą kontraktu, potrzeba zabezpieczenia pewności stanu cywilnego (w tym funkcjonowania zasady mater semper certa est) ${ }^{6}$. I w tych państwach pojawiać się mogą

${ }^{4} \mathrm{Na}$ temat międzynarodowego obrotu osobowego zob. P. Kasprzyk, Akty stanu cywilnego w międzynarodowym obrocie prawnym, cz. 1, „Technika i USC” 2005, nr 4, s. 11-14, cz. 2, 2006, nr 2, s. 6-9; P. Kasprzyk, Pozycja prawna urzędnika stanu cywilnego w Polsce i na Ukrainie, [w:] $Z$ zagadnień prawa rodzinnego i rejestracji stanu cywilnego, red. H. Cioch, P. Kasprzyk, Katolicki Uniwersytet Lubelski Jana Pawła II, Lubelska Szkoła Biznesu Fundacji Rozwoju KUL, cz. 1, „Technika i USC" 2005, nr 4, s. 11-14, cz. 2, 2006, nr 2, Lublin 2007, s. 159-188.

${ }_{5}^{5}$ Zob. M. Mikluszka, Czy można kupić dziecko, czyli problemy prawne i etyczne zwiazane z macierzyństwem zastępczym?, [w:] Wspótczesne wyzwania bioetyczne, red. L. Bo s ek, M. Królikowski, C. H. Beck, Warszawa 2010, s. 322-336. Również odnośnie do polskiej praktyki orzeczniczej lub procedury legislacyjnej występuje spore prawdopodobieństwo zaistnienia postulatów uznawania skutków zagranicznych rozwiązań i dokumentów publicznych dotyczących umownego przenoszenia stanu cywilnego (ojcostwa lub macierzyństwa oraz pochodzenia dziecka).

${ }^{6}$ Zob. więcej: M. Safjan, Prawo wobec ingerencji w naturę ludzkiej prokreacji, Uniwersytet Warszawski, Warszawa 1990, s. 436; M. Nesterowicz, Prawo medyczne, Towarzystwo Naukowe Organizacji i Kierownictwa „Dom Organizatora”, Toruń 2005, s. 218 i in.; A. Czubik, Protection of women's rights and health in international law versus 'surrogacy business', [w:] Fundamental legal problems of surrogate motherhood. Global perspective, ed. P. Mostowik, Wydawnictwo Instytutu Wymiaru Sprawiedliwości, Warsaw 2019, s. 509 i n. 
jednak żądania uznawania skutków procedur, które zostały przeprowadzone za granicą

Warto też zwrócić uwagę, że na świecie widoczne jest również zjawisko odwrotne, swoista renaturyzacja prawa. Można bowiem wskazać przykłady państw, w których najpierw omawiane procedury prawnie wprowadzono albo tolerowano (co doprowadziło m.in. do swoistego eksportu ich rezultatów do państw zachodnioeuropejskich), a następnie w drugiej dekadzie XXI w. jednak ich zakazano (np. Nepal i Kambodża) bądź je ograniczono (Indie, Tajlandia). Zakaz zostal wprowadzony na bazie praktycznych doświadczeń oraz po rozważeniu m.in. argumentów mówiących o handlu dziećmi i uprzedmiotowieniu kobiet. To z kolei doprowadziło do przeniesienia „biznesu reprodukcyjnego” do innych państw, w przeważającej mierze biednych społeczeństw.

\section{Diametralne różnice $w$ zakresie dopuszczalności oraz treści surrogate motherhood}

W literaturze pod terminem „macierzyństwo zastępcze” (surrogate motherhood) rozumie się najczęściej kontraktowe świadczenie polegające na byciu w ciąży i przekazaniu dziecka po porodzie stronie zamawiającej (zlecającej), co służy zaspokojeniu pragnienia posiadania dziecka przez bezpłodną parę (gdy przyczyna bezpłodności leży po stronie kobiety) albo wygodzie kobiety, która może, ale nie chce nosić ciąż̇y. Procedury umożliwiające taki skutek są legalne w niektórych państwach, a ponadto przewiduje się wówczas fikcję prawną, że dziecko pochodzi od osób zamawiających (które wyrażają wolę posiadania dziecka jako inten-

\footnotetext{
${ }^{7}$ Odnośnie do komplikacji rodzących się w postępowaniach administracyjnych, w których pochodzenie dziecka (macierzyństwo lub ojcostwo) jest przesłanką np. nabycia obywatelstwa lub dowodu tożsamości zob. P. Mostowik, Problem obywatelstwa dziecka prawdopodobnie pochodzacego od obywatela polskiego niebędacego mężem surrogate mother. Uwagi aprobujace wyrok NSA z 6.5.2015 r. (sygn. II OSK 2372/13 i II OSK 2419/13), „Problemy Współczesnego Prawa Międzynarodowego, Europejskiego i Porównawczego" 2018, t. 16, s. 55 i n. oraz - co do rzeczywistego stanu prawa międzynarodowego, które bywa w polskich postępowaniach ignorowane - idem, Glosa do wyroku Naczelnego Sądu Administracyjnego z dnia 10 października 2018 r. (sygn. akt II OSK 2552/16), „Zeszyty Naukowe Sądownictwa Administracyjnego” 2019, nr 4, s. 132.

${ }^{8}$ Zob. P. Morciniec, Macierzyństwo zastępcze, [w:] Encyklopedia bioetyki, red. A. Muszala, wyd. 2, Polskie Wydawnictwo Encyklopedyczne, Radom 2009, s. 367-372.
} 
ded parents), określanych na dalszym etapie jego życia (po przejęciu wychowania dziecka) rodzicami socjologicznymi (sociological parents) ${ }^{9}$.

Tym samym prawo regulujące stan cywilny może pomijać fakt macierzyństwa kobiety, która je urodziła, a niekiedy również ojcostwa mężczyzny, od którego dziecko genetycznie pochodzi ( $\mathrm{tj}$. $\mathrm{w}$ razie wykorzystania anonimowego nasienia $\mathrm{z}$ tzw. banku). Możliwe jest więc nabycie statusu matki lub ojca wyłącznie na podstawie kontraktu. Inaczej niż w wypadku przysposobienia (adopcji), prawo dopuszcza fikcję pochodzenia dziecka od osób, które zawarły stosowny kontrakt zamiast genetycznych rodziców bądź kobiety, która je urodziła. W państwach, które powyższe rozwiązanie prawne wprowadziły (tj. w prawie wewnętrznym bądź jako uznawanie skutków działań podjętych np. na wschodzie Europy, w Azji lub niektórych stanach USA), nastąpiły daleko idące zmiany podstawowych zasad prawa rodzinnego. Straciła w szczególności aktualność paremia mater semper certa est, ponieważ występują konkurencyjne sposoby ustalenia pierwotnego macierzyństwa (tj. nie wyłącznie w oparciu o fakt urodzenia).

Od razu trzeba zastrzec, że powyższe rozumienie surrogate motherhood przyjmowane w piśmiennictwie za obcymi ustawodawcami na przełomie XX i XXI w. straciło na aktualności. Obecnie pod tym jednym pojęciem funkcjonuje szereg różnorodnych praktyk i rozwiązań prawnych ${ }^{10}$. W szczególności w niektórych systemach prawnych nastąpiło $\mathrm{w}$ ostatnich latach odejście od - odzwierciedlającej zasady natury (biologii) - reguły, iż dziecko pochodzi od dwóch osób, które są odmiennej płci. Kontraktowe nabycie statusu rodziców dziecka w drodze procedury również zwanej surrogate motherhood może w nich bowiem nastąpić również na rzecz drugiego z „rodziców”, który jest tej samej płci co pierwszy (co oznacza prawną fikcję pochodzenia dziecka od dwóch kobiet lub dwóch mężczyzn), jak również wyłącznie na rzecz jednej osoby (co oznacza prawną fikcję pochodzenia dziecka wyłącznie od jednej kobiety albo jednego mężczyzny). Te ostatnie rozwiązania dotyczące stanu cywilnego, określanego na moment urodzenia się dziecka, przekładają się w praktyce na sprawowanie władzy rodzicielskiej (praw i obowiązków wynikających z prawa rodzinnego) przez osoby, które dziecko w powyższy sposób pozyskały, bez potrzeby jego przysposobienia (adoptio) bądź ustanowienia opieki prawnej (tutela).

\footnotetext{
${ }^{9}$ Zob. więcej: O. Bobrzyńska, Surrogate motherhood (tzw. urodzenie zastępcze): bieżące tendencje w ujęciu prawnoporównawczym, [w:] Fundamentalne prawne problemy surrogate motherhood..., s. 413 i n.

${ }^{10}$ M. Gałązka, J. Haberko, Wybrane zagadnienia macierzyństwa zastępczego, [w:] Szczególne świadczenia zdrowotne system prawa medycznego, t. 2, red. L. Bosek, C. H. Beck, Instytut Nauk Prawnych PAN, Warszawa 2018, s. 41 - autorki celnie podkreślają, że nie ma obecnie jednolitego sposobu regulacji macierzyństwa zastępczego.
} 
W ostatnich latach nastąpiła ewolucja regulacji prawnej, zakresu zastosowania i pojęcia macierzyństwa zastępczego, którą można zobrazować na przykładzie kilku systemów prawnych, o czym niżej. Pozwoli to na zidentyfikowanie szczegółowych, dodatkowych kwestii, które obecnie pojawiać się mogą również $w$ obrocie nieograniczonym do terytoriów państw organizujących omawiane procedury, ale $w$ międzynarodowym ( $w$ tym z perspektywy Polski). Generalna obserwacja ewolucji prawa prowadzi do wniosku, że odnośnie do warunków stawianych osobom zamawiającym dziecko można wyróżnić niejednorodne rozwiązania umożliwiające skorzystanie $\mathrm{z}$ omawianej procedury, zlecane $\mathrm{w}$ :

- celu donoszenia własnego embrionu (w niektórych systemach prawnych de facto nie tylko wtedy, gdy kobieta nie może donosić ciąży i przejść porodu, ale również wtedy, gdy kobieta może, lecz nie chce być w ciąży, np. z wygody lub braku czasu);

- sytuacji bezpłodności lub bezskutecznego leczenia niepłodności, której przyczyny występują po stronie kobiety (tj. z użyciem komórki jajowej innej kobiety, w tym anonimowej);

- sytuacjach, w których trudno mówić o bezpłodności lub niepłodności, ponieważ dziecko nie może biologicznie pochodzić od danej konstelacji osobowej zamawiających (np. jedna osoba lub dwóch mężczyzn) ${ }^{11}$.

\section{Uwagi prawnoporównawcze}

Badania komparatystyczne prowadzą po pierwsze do wniosku, że na świecie dominują porządki prawne, w których nie występują konstrukcje prawne zasygnalizowane na wstępie, a naruszenie prawa ( $w$ tym dotyczącego dopuszczalnych procedur medycznych lub fałszowanie aktów urodzenia) jest penalizowane, umowy z agencjami i tzw. surogatkami traktowane jako nieważne, a ponadto konsekwentnie - skutki procedur przeprowadzanych za granicą ocenia się negatywnie $^{12}$. Część państw wprowadziła do swoich porządków prawnych wyraź-

11 Zob. więcej: International Surrogacy Arrangements. Legal Regulation at the International Level, eds. K. Trimmings, P. B e a um on t, Hart Publishing, Oxford 2013, Studies in Private International Law, Vol. 12.

12 Co do prawa polskiego zob. T. Smyczyński, Stan cywilny, [w:] System Prawa Prywatnego, t. 11: Prawo rodzinne i opiekuńcze, red. T. Smyczyński, wyd. II, C. H. Beck, Warszawa 2014, s. 12. Kwestię potrzeby ochrony podstawowych zasad polskiego prawa rodzinnego w obrocie z zagranicą sygnalizuje P. Mostowik, Pochodzenie dziecka i odpowiedzialność rodzicielska [w:] System Prawa Prywatnego, t. 20C: Prawo prywatne międzynarodowe, red. M. Pazdan, C. H. Beck, Warszawa 2015 , s. 293 i n. 
ny zakaz tej praktyki (np. Francja, Szwajcaria, Hiszpania, Niemcy) ${ }^{13}$. Po drugie badania pokazują, że występujące w niektórych państwach rozwiązania prawne tak nazywane znacznie się różnią - albo od początku ich wprowadzenia, albo na skutek znacznej ewolucji, którą przeszła część z nich. Różnice występują w szczególności w kręgu podmiotów, którym dziecko ma zostać przekazane, oraz warunków po stronie osób zamawiających dziecko i rodzącej je kobiety, w tym warunków skorzystania z procedury, wieku i cech osobistych tzw. surogatki, genetycznej więzi dziecka z nią i osobami zamawiającymi, jak również w kwestii odpłatności na rzecz jej i podmiotów pośredniczących. Odmiennie są również regulowane skutki procedury dotyczące przede wszystkim ustalenia pochodzenia dziecka.

Pierwotną formę surrogate motherhood w ewolucji badanych praw obcych, tj. dotyczących par składających się z kobiety i mężczyzny, których dotknęła niepłodność, stanowią rozwiązania prawne w Rosji i Ukrainie ${ }^{14}$. Ustawodawstwa tych państw przewidują dodatkowe warunki zmierzające do tego, by omawiana procedura była subsydiarna w stosunku do biologicznego macierzyństwa ${ }^{15}$.

$\mathrm{W}$ rosyjskiej doktrynie omawiane procedury są zaliczane do technologii wspierania reprodukcji. W Kodeksie rodzinnym z 1995 r. wystąpiła pierwszy raz wyraźna pośrednia wzmianka - w art. 51 ust. 4 zd. 2 przewidziano możliwość wpisania do ksiąg urodzeń rodziców dziecka urodzonego przez matkę zastępczą pary małżeńskiej, która wyraziła zgodę na implantację embrionu matce zastępczej oraz zakaz powoływania się na fakt przeprowadzenia procedury implantacji

${ }_{13}$ Więcej na temat poszczególnych przepisów zob. O. Bobrzyńska, Macierzyństwo zastępcze w prawie francuskim, Instytut Wymiaru Sprawiedliwości, Warszawa 2017, [on-line:] https://www. iws.org.pl/analizy-i-raporty/raporty\#podstawowe17 - 7 VIII 2019; E. Przyśliwska-Urbanek, Macierzyństwo zastępcze z perspektywy prawa Nierniec, Instytut Wymiaru Sprawiedliwości, Warszawa 2017, [on-line:] https://www.iws.org.pl/analizy-i-raporty/raporty\#podstawowe1 - 7 VIII 2019; ea de m, Macierzyństwo zastępcze z perspektywy prawa Szwajcarii, Instytut Wymiaru Sprawiedliwości, Warszawa 2017, [on-line:] https://www.iws.org.pl/analizy-i-raporty/raporty\#podstawowe17 7 VIII 2019.

${ }^{14}$ Regulacje prawne w przedmiocie urodzenia zastępczego obowiązujące w Rosji i na Ukrainie omawiają odpowiednio J. Berger, Macierzyństwo zastępcze w świetle przepisów prawa Federacji Rosyjskiej, Instytut Wymiaru Sprawiedliwości, Warszawa 2017; M. Zeniv, Macierzyństwo zastępcze w prawie ukraińskim, Instytut Wymiaru Sprawiedliwości, Warszawa 2017, [on-line:] www.iws. org.pl/analizy-i-raporty/raporty\#podstawowe17 - 7 VIII 2019.

15 W Rosji z usług surogatki może ponadto skorzystać samotna kobieta, która nie może donosić ciąży i urodzić dziecka z przyczyn medycznych. Wśród podmiotów uprawnionych do skorzystania $\mathrm{z}$ procedury surogacji nie został wymieniony samotny mężczyzna. $\mathrm{W}$ orzecznictwie sądów rosyjskich pojawiają się natomiast pojedyncze orzeczenia nakazujące rejestrację urodzenia dzieci urodzonych przez matkę zastępczą i przekazanych samotnemu mężczyźnie (dawcy nasienia). Zob. J. Berger, op. cit., s. 10. 
embrionów w przypadku kwestionowania macierzyństwa lub ojcostwa. Z art. 55 ust. 9 ustawy o podstawach ochrony zdrowia obywateli z 2011 r. wynika, że pojęcie „macierzyństwo zastępcze” obejmuje noszenie i urodzenie dziecka na podstawie umowy zawartej między matką zastępczą, tj. kobietą, która nosi płód po przeniesieniu embrionu dawcy, a potencjalnymi rodzicami, których komórki zostały wykorzystane do zapłodnienia, lub samotną kobietą, dla których noszenie i urodzenie dziecka jest niemożliwe ze względów medycznych. Art. 55 ust. 3 tej ustawy mówi, że prawo do korzystania z technologii wsparcia reprodukcji przysługuje mężczyźnie i kobiecie będącym lub niebędącym w związku małżeńskim pod warunkiem udzielenia dobrowolnej, świadomej, dwustronnej zgody na interwencję medyczną, jak również samotnej kobiecie pod warunkiem udzielenia dobrowolnej, świadomej zgody na interwencję medyczną. Ustawodawstwo rosyjskie nie reguluje ani samej procedury macierzyństwa zastępczego, ani kwestii umowy między matką zastępczą a rodzicami genetycznymi. Szczegółowo uregulowano natomiast wymagania stawiane tzw. surogatce, co powoduje w praktyce większe prawdopodobieństwo dobrej ,jakości” zakontraktowanego dziecka. Kobieta ta powinna być w wieku 20-35 lat, być matką co najmniej jednego zdrowego dziecka i przedstawić zaświadczenie lekarskie o dobrym stanie zdrowia. Matka zastępcza nie może być jednocześnie dawcą komórki jajowej, co również w praktyce służy minimalizacji problemów, które w razie przeciwnego rozwiązania mogłyby dotknąć zamawiających (np. odmowa wydania urodzonego dziecka, które genetycznie pochodzi od tzw. surogatki) ${ }^{16}$. Warto zwrócić również uwagę, że do dalszego poszerzenia zakresu zastosowania omawianych procedur doprowadziła w Rosji prawotwórcza działalność sądów. Powołując się na art. 16 ust. 5 ustawy o aktach stanu cywilnego (wpisywanie do księgi urodzeń „osób, które będąc w związku małżeńskim, wyraziły pisemną zgodę na implantację embrionu innej kobiecie w celu noszenia i urodzenia dziecka"), organy administracji odmawiały rejestracji jako rodziców osób niebędących ze sobą w związku małżeńskim oraz samotnych kobiet i mężczyzn. Następnie sądy uznawały takie żądania, mimo że Kodeks rodzinny nie zawiera przepisów regulujących rejestrację takiego urodzenia dziecka na rzecz samotnej kobiety bądź mężczyzny ${ }^{17}$.

Również w prawie ukraińskim widoczne jest założenie subsydiarności tzw. macierzyństwa zastępczego oraz prawotwórcza działalność sądów. Zgodnie z ust. 6.1 nakazu Ministerstwa Ochrony Zdrowia wśród przesłanek (warunków) znalazły się:

16 Zob. więcej: ibidem, s. 12.

${ }^{17}$ Np. wyrok sądu w Nowosybirsku z 2015 r. w sprawie G. Vaśkin przeciwko Nowosybirskiemu Centrum Medycyny Reprodukcyjnej Sp. z o.o. Zob. ibidem. 
1) Istnienie odpowiednich wskazań medycznych związanych z chorobami macicy, ale też „ciężkie choroby somatyczne, przy których donoszenie ciąży stanowi zagrożenie dla zdrowia lub życia pacjenta, lecz nie wywierają wpływu na zdrowie przyszłego dziecka” oraz „nieudane powtarzające się próby stosowania technik wspomaganej reprodukcji (cztery i więcej razy), które doprowadziły do ciąży (...).

2) Genetyczne pochodzenie dziecka od małżonków albo jednego z nich.

3) Brak genetycznego pochodzenia dziecka od tzw. matki zastępczej (prócz relacji między bliskimi krewnymi)"18.

20 września 2011 r. nastąpiła zmiana art. 123 ust. 2 Kodeksu rodzinnego Ukrainy, drogą której dookreślono, że do udziału w procedurze macierzyństwa zastępczego jest uprawnione małżeństwo, przez które zgodnie z prawem ukraińskim należy pojmować związek kobiety i mężczyzny. Aktywizm sędziowski doprowadził do naruszenia tej zasady $w$ praktyce, ponieważ dopuszczono zamówienie dziecka przez samotną (pojedynczą) kobietę. Na rzecz par homoseksualnych mężczyzn w praktyce dokonuje się zaś najpierw ustalenia ojcostwa na rzecz jednego $z$ nich wraz ze zrzeczeniem się praw rodzicielskich przez matkę, a następnie - już w innym państwie - następuje „doprzysposobienie” na rzecz drugiego $\mathrm{z}$ nich ${ }^{19}$.

Natomiast rozwiązania prawne w Zjednoczonym Królestwie ${ }^{20}$ ukazują zrede- $^{-}$ finiowane ujęcie i wybiegają poza koncepcję urodzenia zastępczego, która została ugruntowana pod koniec XX w. Obejmują one również umowę ze skutkiem pozyskania stanu cywilnego pierwotnych (tj. nieadopcyjnych) rodziców przez dwie kobiety lub dwóch mężczyzn, których nie tyle dotknęła in concreto bezpłodność lub niepłodność, ile od których in genere dziecko biologicznie pochodzić nie moż $\mathrm{e}^{21}$. Tym samym rodzą one również fikcję prawną pochodzenia dziecka od dwóch osób tej samej płci, która znajduje odbicie w zagranicznej rejestracji stanu cywilnego i orzeczeniach sądowych. Od początku 2019 r. umożliwione jest ponadto nabycie statusu rodzica posiadającego wyłączną władzę rodzicielską nad dzieckiem urodzonym przez surogatkę również przez pojedyncze osoby ${ }^{22}$.

\footnotetext{
${ }_{18}$ Za: M. Zeniv, op. cit., s. 10.

19 Zob. więcej: ibidem, s. 8.

${ }^{20} \mathrm{Na}$ temat rozwiązań przyjętych w prawie Zjednoczonego Królestwa zob. np. M. Wells - Gre co, The status of children arising from inter-country surrogacy arrangements. The past, the present, the future, Eleven International Publishing, Hague 2016, s. 159-191; O. Bobrzyńska, Macierzyństwo zastępcze w prawie Zjednoczonego Królestwa, Instytut Wymiaru Sprawiedliwości, Warszawa 2017, [on-line:] https://www.iws.org.pl/analizy-i-raporty/raporty\#podstawowe17 - 7 VIII 2019.

${ }^{21}$ Zgodnie z sec. 54 (2) Human Fertilisation and Embryology Act z 2008 r.

22 Dnia 3 stycznia 2019 r. wszedł w życie The Human Fertilisation and Embryology Act 2008 (Remedial) Order 2018. Tekst aktu dostępny na stronie internetowej: https://www.legislation.gov.uk/
} 
W odwrotnym kierunku poszły natomiast Indie, Nepal, Kambodża i Tajlandia, gdzie w ostatnich latach wprowadzono ograniczenia w dostępie do surogacji lub zakazano tej praktyki. Np. w Indiach z kręgu osób zamawiających wyłączono najpierw pojedyncze osoby i pary homoseksualne, a następnie cudzoziemców. Obecnie przedmiotem obrad parlamentarnych jest projekt ustawy, zgodnie z którym wyłączona będzie surogacja komercyjna. Dopuszczalna ma być surogacja altruistyczna co do zasady tylko dla hinduskich par małżeńskich (kobiety i mężczyzny), o ile uzasadniają ją powody medyczne. Tzw. surogatka będzie musiała być spokrewniona z jednym z małżonków. W Tajlandii w 2015 r. zniesiono surogację komercyjną i wyłączono działalność agencji pośredniczących oraz ograniczono dostęp do surogacji tylko dla tajskich par (mężczyzny i kobiety) małżeńskich ${ }^{23}$. Nepal i Kambodża zakazały natomiast surogacji ${ }^{24}$.

Do zaostrzenia warunków przeprowadzenia procedury przyczyniły się nadużycia, w tym sprawy, które odbiły się szerokim echem w prasie światowej. W Tajlandii należały do nich sprawa Baby Gammy oraz sprawa z udziałem zamożnego japońskiego przedsiębiorcy Mitsutoki Shigeta. W pierwszej tajska surogatka urodziła w grudniu 2013 r. bliźniaki - chłopca Gammy oraz dziewczynkę Pipah. Dziewczynka została zabrana przez osoby zamawiające pochodzące z Australii. Chłopiec, dotknięty zespołem Downa, pozostał natomiast pod opieką tajskiej surogatki (jeszcze w trakcie ciąży była ona przez agencję pośredniczącą nakłaniana do aborcji) ${ }^{25}$. Wspomniany Japończyk został ojcem 16 dzieci urodzonych przez surogatki i planował udział w kolejnych procedurach ${ }^{26}$.

uksi/2018/1413/contents/made - 5 IX 2019. Na temat przebiegu prac parlamentarnych zob. sprawozdanie z 3 kwietnia 2019 r.: T. J a r rett, Children. Surrogacy - single people and parental orders (UK), [on-line:] https://researchbriefings.parliament.uk/ResearchBriefing/Summary/CBP-8076 5 IX 2019.

${ }^{23}$ Jeżeli tylko jedno z małżonków posiada tajskie obywatelstwo, związek małżeński musi trwać co najmniej trzy lata. Przepisy ustawy z 2015 r. omawia S. Hongla d a ro m, Surrogacy law in Thailand, [on-line:] https://www.researchgate.net/publication/322286708_SURROGACY_LAW_IN_THAI LAND - 26 VII 2018.

${ }^{24} \mathrm{Na}$ temat zmian w regulacjach krajowych państw azjatyckich zob. Permanent Bureau of the HCCH, The Cross-Border Recognition of Parent-Child Relationship Statuses (Parentage), Including International Surrogacy Arrangements - An Update on the Work of the Hague Conference on Private International Law (HCCH), [w:] Protecting the Rights of Families and Children in a Changing World, ed. B. de Hart, T. Li efaard, T. M. C. Asser Press, Hague 2017, s. 105-106, Mededelingen van de Koninklijke Nederlandse Vereniging voor Internationaal Recht, $\mathrm{nr} 144$.

${ }^{25} \mathrm{~J}$. Campbell, The "baby Gammy" case dealing with commercial surrogacy. What happened to baby Pipah? - Farnell \& Anor and Chanbua (2016) FLC 93-700, [on-line:] http://www.woltersklu wercentral.com.au/legal/family-law/baby-gammy-case-dealing-commercial-surrogacy-happen ed-baby-pipah-farnell-anor-chanbua-2016-flc-93-700 - 24 VIII 2018.

${ }^{26}$ Zob. Mitsutoki Shigeta: 'Baby factory' dad wins paternity rights, [on-line:] https://www.bbc. co.uk/news/world-asia-43123658 - 24 VIII 2018. 
Badania prawnoporównawcze prowadzą też do wniosku, że różny może być krąg osób dopuszczonych do skorzystania z procedury (pary składające się $\mathrm{z}$ kobiety i mężczyzny pozostające $\mathrm{w}$ związku małżeńskim albo $\mathrm{w}$ związku niesformalizowanym, pary osób tej samej płci, pojedyncze osoby) ${ }^{27}$. Obecnie można zaobserwować przeciwstawne tendencje do rozszerzania i zawężania kręgu osób, które mogą skorzystać z usług surogatki. W Zjednoczonym Królestwie krąg ten w ostatnich latach został poszerzony. Odwrotny kierunek obrały natomiast państwa azjatyckie, w których surogacja była praktykowana na bardzo dużą skalę i stanowiła $w$ istocie dochodowy biznes dla klinik medycznych i agencji pośredniczących oraz formę zarobku kobiet, często w bardzo złej sytuacji materialnej, których decyzja o urodzeniu dziecka jest podyktowana przede wszystkim chęcią wydobycia się z biedy.

Niektóre ustawodawstwa precyzyjnie określają warunki, które musi spełniać tzw. surogatka, np. być w optymalnym wieku do rodzenia dzieci (w Rosji przedział wiekowy został określony na 20-35 lat), urodzić wcześniej dziecko (takie wymaganie jest przewidziany np. w Rosji i Tajlandii oraz Ukrainie), a nawet co do zasady - być spokrewniona z jedną z zamawiających osób (regulacja tajska wyklucza przy tym kobiety będące rodzicami lub zstępnymi którejkolwiek z osób zamawiających).

Warto zwrócić uwagę, że duże różnice występują również odnośnie do komercyjności omawianych procedur. Dane prawo może przewidywać zapłatę wynagrodzenia na rzecz rodzącej (np. prawa ukraińskie, rosyjskie, stanu Kalifornia) albo dopuszczać jedynie tzw. surogację altruistyczną za zwrotem uzasadnionych wydatków (np. prawo Zjednoczonego Królestwa, prawo greckie). Osobną kwestię stanowi to, jak wymaganie altruizmu tzw. surogatki jest w praktyce egzekwowane i czy zapłata nie kryje się pod zwrotem wydatków.

Ponadto może występować wymaganie, by materiał genetyczny pochodził przynajmniej od jednej osoby zamawiającej (taki wymóg przewidują np. prawo Zjednoczonego Królestwa, prawo ukraińskie). Niektóre ustawodawstwa dopuszczają formę tzw. tradycyjnego urodzenia zastępczego (gdy zapłodnieniu podlegają gamety surogatki), inne zaś przewidują jedynie surogację gestacyjną, tj. procedurę, w której gamety pochodzą od kobiety zamawiającej lub trzeciej kobiety dawczyni (np. prawa ukraińskie, tajskie). Obie formy dopuszcza prawo Zjednoczonego Królestwa.

\footnotetext{
${ }_{27}$ Zob. więcej: J. Hab erko, Dopuszczalność stosowania technik wspomaganego medycznie rozrodu w przypadku zwiazków partnerskich - de lege lata i de lege ferenda, [w:] Zwiazki partnerskie. Debata na temat projektowanych zmian prawnych, red. M. Andr zejewski, Towarzystwo Naukowe Organizacji i Kierownictwa „Dom Organizatora”, Toruń 2013, s. 157-170.
} 
Ustalenie pochodzenia dziecka od osób zamawiających może zostać uregulowane jako następujące $z$ mocy prawa (tj. „automatyczne” - np. w prawach tajskim i ukraińskim) bądź wymaga przeprowadzenia dodatkowej sądowej procedury. Np. w Zjednoczonym Królestwie w specjalnym postępowaniu wszczynanym po urodzeniu dziecka sąd wydaje parental order. W postępowaniu tym, niezależnie od tego, czy procedura urodzenia zastępczego została przeprowadzona w kraju czy zagranicą, sąd weryfikuje, czy zostały spełnione wymogi przewidziane w prawie angielskim ${ }^{28}$, w tym wspomniane powyżej dotyczące wnioskodawców, związku genetycznego dziecka z przynajmniej jedną z osób wnioskujących o wydanie parental order, kosztów poniesionych przez wnioskodawców. Pochodzenie dziecka jest zatem ustalane zgodnie $\mathrm{z}$ prawem angielskim ${ }^{29}$.

\section{Kwestia (nie)uznawania skutków zagranicznych procedur i rejestracji stanu cywilnego}

Warto zauważyć, że odmienne są też ogólne rozwiązania prawne oraz postulaty uznawania skutków zastosowania obcego prawa (w tym zagranicznych procedur z tzw. zastępczą matką oraz rejestracji stanu cywilnego) w państwach, w których zasadą jest macierzyństwo kobiety, która urodziła dziecko, powiązane z ojcostwem, oraz zasada nieprzenoszalności stanu cywilnego drogą kontraktu. Badanie stanu prawnego w wybranych państwach, które - podobnie jak Polska $\mathrm{w}$ krajowym prawie materialnym nie przewidują surrogate motherhood (Austria, Francja, Niemcy, Włochy, Szwajcaria ${ }^{30}$ ), prowadzą do wniosku, że mimo tego negatywnego podejścia prawa materialnego de facto podobne konsekwencje mogą w nich jednak zaistnieć drogą prawotwórczego orzecznictwa (aktywizmu sędziowskiego) przy zastosowaniu reguł prawa prywatnego międzynarodowego i międzynarodowego postępowania cywilnego ${ }^{31}$. W niektórych państwach eu-

\footnotetext{
${ }^{28}$ Warunki te są przewidziane w sec. 54 Human Fertilisation and Embryology Act z 2008 r. (przepisy te weszły w życie 6 kwietnia 2010 r.). Aktualny tekst ustawy dostępny na stronie internetowej: http://www.legislation.gov.uk/uksi/2010/987/pdfs/uksi_20100987_en.pdf - 12 IX 2018.

${ }_{29}$ Zob. K. Trimmings, P. Beaumont, Parentage and surrogacy in a European perspective, [w: European Family Law, Vol. 3: Family law in a European perspective, ed. J. M. Scherpe, Edward Elgar Publishing, Cheltenham 2016, s. 263.

${ }^{30}$ Przegląd rozwiązań prawnych zob. np. L. Brunet et al., A Comparative Study on the Regime of Surrogacy in EU Member States, Luxembourg 2013; International Surrogacy Arrangements...; M. Wells-Greco, The status of children arising...

${ }_{31}$ Zob. M. Wojewoda, Transkrypcja aktu urodzenia dziecka, które zostato uznane za granica, „Kwartalnik Prawa Prywatnego” 2017, nr 2, s. 347-350.
} 
ropejskich mimo krytyki i zakazu surogacji dochodzi w istocie do „uznawania” skutków procedur dokonanych za granicą w drodze transkrypcji zagranicznych aktów urodzenia.

Znamienity przykład różnej i zmiennej argumentacji w kwestii skutków umowy o surogację zawartych i zrealizowanych za granicą stanowi orzecznictwo sądów i organów francuskich. Od przeszło 20 lat prawo francuskie wyraźnie przewiduje sankcję nieważności umowy dotyczącej poczęcia lub ciąży na rzecz innych osób ${ }^{32}$. Z przepisu tego wywodzony jest zakaz surogacji ${ }^{33}$. Zasada ta stanowi przy tym zasadę porządku publicznego ${ }^{34}$. Odmowa transkrypcji aktów urodzenia dzieci urodzonych przez surogatkę za granicą była uzasadniana naruszeniem zasady niezbywalności stanu cywilnego i sprzecznością z porządkiem publicznym ${ }^{35}$, a następnie również obejściem prawa ${ }^{36}$. Za podtrzymaniem zakazu surogacji opowiada się francuski Krajowy Komitet Konsultacyjny ds. Etyki, Nauk o Życiu i Zdrowiu, wskazując, że w świetle zasad poszanowania istoty ludzkiej i niezbywalności ciała ludzkiego oraz niezgody na wykorzystywanie kobiet i uprzedmiotowienie dziecka nie istnieje „etyczna” postać surogacji ${ }^{37}$.

Mimo niezmiennej treści przepisów negatywne stanowisko orzecznictwa uległo częściowo zmianie w wyniku orzeczeń Europejskiego Trybunału Praw Człowieka z 16 czerwca 2016 r. w sprawach Mennesson przeciwko Francji i Labassee przeciwko Francji ${ }^{38}$, nakazujących uznanie stosunku pochodzenia dziecka od ojca biologicznego w imię chronionego art. 8 Europejskiej konwencji

32 Art. 16-7 fr. k.c. wprowadzony ustawą nr 94-653 z dnia 29 lipca 1994 r. dotyczącą poszanowania ludzkiego ciała.

33 F. Monéger, La gestation pour autrui, „Revue Internationale de Droit Comparé” 2010, vol. 62, no. 2, s. 234 .

34 Art. 16-9 fr. k.c.

35 Zob. np. orzeczenie sądu kasacyjnego nr 371 z dnia 6 kwietnia 2011 r., skarga nr 09-17.130, https://www.courdecassation.fr/jurisprudence_2/premiere_chambre_civile_568/371_6_19627. html - 12 IX 2018.

36 Zob. np. Arrêt no. 281 du 19 mars 2014 (13-50.005), Cour de cassation, Première chambre civile [Orzeczenie sądu kasacyjnego nr $281 \mathrm{z}$ dnia 19 marca 2014 r., skarga nr 13-50.005], [on-line:] https://www.courdecassation.fr/jurisprudence_2/premiere_chambre_civile_568/281_19_28731. html - 12 IX 2018.

37 Comité Consultatif National d'Ethique pour les sciences de la vie et de la santé, Avis du CCNE du 15 juin 2017 sur les demandes sociétales de recours à l'assistance médicale à la procréation (AMP) [Opinia nr $126 \mathrm{z}$ dnia 15 czerwca 2017 r. na temat zapotrzebowania społecznego na techniki wspomaganego rozrodu], s. 40, [on-line:] https://www.ccne-ethique.fr/sites/default/files/pub lications/ccne_avis_ndeg126_amp_version-def.pdf - 5 IX 2019; Avis 129, Contribution du Comité consultatif national déthique à la révision de la loi de bioéthique 2018-2019, s. 124, [on-line:] https:// www.ccne-ethique.fr/sites/default/files/avis_129_vf.pdf - 5 IX 2019.

38 Skarga nr 65192/11, Mennesson przeciwko Francji oraz skarga nr 65941/11, Labassee przeciwko Francji, polskie opracowanie autorstwa M. A. Nowickiego dostępne na stronie internetowej: 
praw człowieka z 1950 r. ${ }^{39}$ prawa dziecka do poszanowania życia prywatnego, w tym tożsamości. Sądy francuskie dopuszczają zatem obecnie transkrypcję zagranicznych aktów urodzenia w zakresie, w jakim jako ojciec dziecka wpisany jest mężczyzna, od którego dziecko biologicznie pochodzi. W kwestii rejestracji w księgach stanu cywilnego jako matki kobiety, której dziecko zostało przekazane, ETPC wypowiedział się na kanwie sprawy rodziny Mennesson w opinii wydanej w składzie Wielkiej Izby 10 kwietnia 2019 r. na wniosek francuskiego sądu kasacyjnego. Trzeba podkreślić, że sprawa ta dotyczy rodziców „zamierzonych” (intended parents), będących kobietą i mężczyzną pozostających w związku małżeńskim. Stąd rozstrzygany problem nie obejmował innego niż naturalny, żeńsko-męski koncept prawnego pochodzenia dziecka lub rodzicielstwa (tj. nie dotyczył sytuacji określanej jako pseudo-surrogacy ${ }^{40}$ ). ETPC wskazał w tej opinii, że prawo dziecka do poszanowania życia prywatnego wymaga, aby prawo krajowe przewidywało możliwość uznania „jakiegoś” stosunku prawnego między dzieckiem a matką „zamierzoną” („possibility of recognition of a legal parent-child relationship with the intended mother"), wskazana jako matka w zagranicznym dokumencie. Jednocześnie wskazano, że ochrona prawa dziecka do życia prywatnego oraz uwzględnienia dobra dziecka nie oznacza jednak, że państwo ma obowiązek transkrypcji z zagranicznego aktu urodzenia wpisu dotyczącego matki „zamierzonej”. Usankcjonowanie więzi rodzicielskiej może również nastąpić w drodze innych środków, np. przez adopcję ${ }^{41}$. ETPC wskazał brak konieczności przeniesienia do kraju treści zagranicznego aktu urodzenia oraz nie dookreślił rodzaju innego rozwiązania prawnego, które w rozpatrywanym stanie faktycznym byłoby pożądane. Egzemplifikacja adopcji to w istocie kilka rozwiązań (np. przysposobienie pełne lub niepełne), a poza tym do rozważenia mogą być inne stosunki prawne między dzieckiem a kobietą, zależnie od prawa krajowego, np. przyznanie uprawnień do wykonywania władzy rodzicielskiej, osobna kon-

http://www.hfhr.pl/wp-content/uploads/2015/11/Omowienie_orzeczenia_Mennesson_przeciwko_Francji.pdf - 7 VIII 2019.

${ }^{39}$ Konwencja o ochronie praw człowieka i podstawowych wolności, sporządzona w Rzymie dnia 4 listopada 1950 r., zmieniona następnie Protokołami nr 3, 5 i 8 oraz uzupełniona Protokołem nr 2, Dz.U. z 1993 r. Nr 61 poz. 284 ze zm. [dalej: konwencja rzymska z 1950 r., e.k.p.c.].

${ }^{40} \mathrm{Na}$ temat zasadniczych różnic między surrogate motherhood w wersji stricte sensu largo i pseudo - zob. P. Mostowik, Obyś żyt winteresujących czasach, [w:] Fundamentalne problemy prawne surrogate motherhood..., s. 35.

${ }^{41}$ Europejski Trybunał Praw Człowieka, Advisory opinion concerning the recognition in domestic law of a legal parent-child relationship between a child born through a gestational surrogacy arrangement abroad and the intended mother, [on-line:] https://hudoc.echr.coe.int/eng\#\{\%22item id\%22:[\%22003-6380464-8364383\%22]\} - 5 IX 2019. 
strukcja prawa i obowiązku kontaktów z dzieckiem (osobistej styczności), piecza zastępcza, opieka prawna, kuratela. O doborze środka decyduje prawo krajowe przy założeniu, że środek może zostać wdrożony szybko i efektywnie, w zgodzie $\mathrm{z}$ interesem dziecka.

W zgodzie z opinią ETPC pozostaje orzeczenie niemieckiego Federalnego Sądu Najwyższego (Bundesgerichtshof, BGH) z 20 kwietnia 2019 r. Sąd orzekał w sprawie dziecka urodzonego przez surogatkę w Ukrainie i przekazanego niemieckiemu małżeństwu, które zabrało dziecko do Niemiec. Stosunek pochodzenia został ustalony zgodnie $\mathrm{z}$ właściwym w sprawie prawem niemieckim. W świetle tego prawa za ojca dziecka został uznany mężczyzna, któremu dziecko zostało przekazane, będący ojcem biologicznym. Za matkę uznawana jest zaś kobieta, która dziecko urodziła. To ona zatem powinna zostać wpisana w księgach stanu cywilnego. Żona ojca, aby uzyskać status matki, musi natomiast przeprowadzić procedurę adopcyjną ${ }^{42}$, którą przewiduje to prawo lokalne ${ }^{43}$. Warto przy tym zwrócić uwagę, że również w Polsce sąd najczęściej będzie stosował własne prawo przy rozpatrywaniu żądań przeniesienia treści zagranicznej rejestracji (transkrypcji) stanu cywilnego do krajowego rejestru, ponieważ sprawy te dotyczą polskich obywateli, a zgodnie $\mathrm{z}$ art. 55 prawa prywatnego międzynarodowego właściwe jest wówczas prawo ojczyste ${ }^{44}$.

Podobny kierunek obrał również włoski Sąd Najwyższy (Corte Suprema di Cassazione) w wyroku z 8 maja 2019 r. Warto mieć przy tym na względzie, że rozpoznana sprawa dotyczyła nie tylko kwestii możliwości kontraktowania z surrogate mother, ale również - osobnego jurydycznie - problemu prawnego rozumienia pochodzenia dziecka (filiacji). Wyrok zapadł bowiem w stanie faktycznym, w którym w zagranicznym (kanadyjskim) akcie urodzenia jako „rodzice” została wpisana para mężczyn. Sąd włoski orzekt, że do krajowych ksiąg stanu cywilnego zostanie wpisany (transkrybowany) tylko ojciec biologiczny dziecka, ponieważ drugi z mężczyzn nie mieści się w pojęciu matki lub ojca. Takiego orzeczenia wymaga w ocenie sądu przestrzeganie przewidzianego we włoskim prawie zakazu macierzyństwa zastępczego, który stanowi zasadę porządku pub-

\footnotetext{
${ }^{42}$ Wyrok z dnia 20 kwietnia 2019 r., No XII ZB 530/17, [on-line:] http://juris.bundesgerichtshof. de/cgi-bin/rechtsprechung/document.py?Gericht=bgh\&Art=en\&az=XII\%20ZB\%20530/17\&nr= 94770 - 5 IX 2019.

${ }^{43}$ Zob. więcej: E. Figura-Góralczyk, Uwagi dotyczące orzeczenia Niemieckiego Sądu Związkowego z 20 marca 2019 (BGH XII ZB 530/17), [w:] Fundamentalne prawne problemy surrogate motherhood..., s. 521.

${ }_{44}$ Zob. więcej: P. Mostowik, Komentarz do art. 55, [w:] Prawo prywatne międzynarodowe. Komentarz, red. J. Poczobut, Wolters Kluwer Polska, Warszawa 2017, s. 846.
} 
licznego i ma na celu ochronę godności kobiety i instytucji przysposobienia. Sąd nie wykluczył, że ustalenie więzi prawnej z drugą osobą, niezwiązaną genetycznie z dzieckiem, może nastąpić $\mathrm{w}$ drodze odpowiednich instytucji prawnych ${ }^{45}$, innych niż filiacja, co jednak zależy od spełnienia wymagań danego systemu krajowego prawa rodzinnego (tutaj: włoskiego).

Orzecznictwo sądów angielskich stanowi natomiast przykład ewolucji polegającej na tym, że ocena zgodnie $z$ prawem angielskim procedur przeprowadzonych za granicą może prowadzić do rozluźnienia kryteriów przewidzianych w tym prawie. Dotyczy to wydawania parental order w sprawach dzieci urodzonych w państwie, którego prawo przewiduje surogację komercyjną (np. w stanie Illinois lub Kalifornia). Orzecznictwo akceptuje wynagrodzenie na rzecz surogatki i pośredników, jeżeli odpowiada ono kosztom ponoszonym zwykle w państwie, w którym umowa o urodzenie zastępcze została zawarta, nawet jeśli koszty te znacznie przewyższają ,uzasadnione wydatki” przewidziane w prawie angielskim ${ }^{46}$.

Kwestia (nie)uznawania skutków zagranicznych procedur i rejestracji stanu cywilnego występuje nie tylko w państwach, których prawo przewiduje nieważność umowy z tzw. surogatką. Również w państwach dopuszczających niektóre formy surrogate motherhood pytanie o nieuznawanie skutków zagranicznych procedur dotyczy pozostałych form, które wykraczają poza własne rozumienie oraz warunki (np. surogacja za wynagrodzeniem, na rzecz pojedynczych osób albo na rzecz par osób homoseksualnych). Odpowiedź na to pytanie może być w nich negatywna.

Między innymi z powyższych powodów, jak również z uwagi na brak kompetencji Unii Europejskiej w zakresie materialnego prawa rodzinnego niepowodzeniem zakończyła się inicjatywa Komisji UE wzajemnego uznawania skutków rejestracji stanu cywilnego (np. statusu rodziców) ogłoszona w 2010 r. ${ }^{47}$ Propozycje rozwiązań prowadzących do uznawania sytuacji prawnych związanych ze stanem cywilnym (np. stosunku rodzicielstwa), powstałych $w$ innym państwie członkowskim ${ }^{48}$ spotkały się z krytyką państw członkowskich i zostały odrzuco-

${ }_{45}$ Zob. komunikat w sprawie wyroku włoskiego Sądu Najwyższego z 8 maja 2019 r., [on-line:] http://www.cortedicassazione.it/corte-di-cassazione/it/dett_cst.page;ssessionid=29C8B69EC5DD DC182EFE2B5999CF10B1.jvm1?contentId=CST22683 - 5 IX 2019.

${ }^{46}$ Zob. orzeczenie High Court of Justice z 8 grudnia 2010 r. w sprawie Re L (A minor) [2010] EWHC 3146, pkt 10.

47 Zielona Księga „Ograniczenie formalności administracyjnych w stosunku do obywateli - swobodny przepływ dokumentów urzędowych i uznawanie skutków powodowanych przez akty stanu cywilnego" COM/2010/747.

${ }^{48}$ Propozycje zawarte w księdze omawia P. Mostowik, O planach ujednolicenia regut dowodzenia oraz wzajemnej skuteczności rejestracji stanu cywilnego w państwach członkowskich Unii Europej- 
ne w toku prac legislacyjnych zakończonych przyjęciem w lipcu 2016 r. rozporządzenia nr 1191/2016 w sprawie promowania swobodnego przepływu obywateli poprzez uproszczenie wymogów dotyczących przedkładania określonych dokumentów urzędowych w Unii Europejskiej ${ }^{49}$.

\section{Dyskusyjne postulaty unormowania na poziomie międzynarodowym}

Problem surogacji był przedmiotem zainteresowania Rady Europy. Od lat 80 . XX w. w łonie Rady Europy przygotowano szereg dokumentów dotyczących urodzenia zastępczego. Wyłania się z nich sceptyczna ocena zjawiska przy jednoczesnym pragmatycznym podejściu wobec porządków prawnych dopuszczających procedury urodzenia zastępczego. Począwszy od raportu na temat sztucznej prokreacji ludzkiej z 1989 r. zawierającego negatywne stanowisko w kwestii omawianego procederu ${ }^{50}$, skończywszy na raporcie na temat praw dziecka związanych z surogacją z 2016 r., w którym zawarto postulat zakazu surogacji komercyjnej, ewentualnie ograniczenia dostępu do tej procedury dla obywateli rezydujących w danym państwie, w celu ograniczenia problemów wynikających z przypadków tzw. cross-border surrogacy ${ }^{51}$, oraz zalecono współpracę w $\mathrm{HCCH}$ w razie przygotowania przez tę organizację konwencji międzynarodowej. Postulat sporządzenia przewodnika w celu ochrony praw dzieci w związku z zawieraniem umów o urodzenie zastępcze został jednak odrzucony przez Zgromadzenie Parlamentarne Rady Europy.

skiej (Zielona ksiega z 14 grudnia 2010 r.), „Metryka. Studia z zakresu prawa osobowego i rejestracji stanu cywilnego" 2011, nr 1, s. 63-108.

49 Rozporządzenie Parlamentu Europejskiego i Rady (UE) 2016/1191 z dnia 6 lipca 2016 r. w sprawie promowania swobodnego przepływu obywateli poprzez uproszczenie wymogów dotyczących przedkładania określonych dokumentów urzędowych w Unii Europejskiej i zmieniające rozporządzenie (UE) nr 1024/2012, Dz.Urz.UE L 200, s. 1. Na temat rozporządzenia zob. P. Mostowik, Kwestia zakresu zastosowania rozporzadzenia UE nr 1191/2016 do zagranicznej rejestracji stanu cywilnego, „Rodzina i Prawo” 2016, nr 37, s. 97-107.

${ }_{50}$ Ad Hoc Committee of Experts on Progress in the Biomedical Sciences - CAHBI, Report on human artificial procreation, [on-line:] https://rm.coe.int/16803113e4 - 24 VII 2018.

${ }^{51} \mathrm{P}$. de Sutter, Children's rights related to surrogacy, [on-line:] http://assembly.coe.int/nw/xml/ XRef/Xref-XML2HTML-EN .asp?fileid=23015\&lang=en -24 VII 2018, w ramach Komitetu Spraw Społecznych, Zdrowia i Zrównoważonego Rozwoju (Committee on Social Affairs, Health and Sustainable Development). 
Warto natomiast zauważyć, że w ostatnim czasie Wielka Izba Europejskiego Trybunału Praw Człowieka wydała wyrok w sprawie Paradiso i Campanelli przeciwko Włochom ${ }^{52}$, w którym zmodyfikowane wcześniejsze orzeczenie w tej sprawie wydano w mniejszym składzie (siedmiu sędziów). Stwierdzono brak naruszenia art. 8 konwencji rzymskiej z 1950 r. także względem dziecka, które nie było związane genetycznie z jego nabywcą od surogatki. Podkreślono, że art. 8 EKPC nie gwarantuje prawa do założenia rodziny ani prawa do „otrzymania” adoptowanego dziecka. W uzasadnieniu, w przeciwieństwie do wcześniejszego orzeczenia zapadłego w węższym składzie, podkreślono, że nad subiektywną, indywidualną wolą posiadania dziecka przeważają pewne ogólne uzasadnione dobra, w szczególności konieczność wzięcia pod uwagę więzi biologicznej, zwłaszcza z uwagi na krótki okres osobistej styczności ${ }^{53}$.

Trudno w przyszłości spodziewać się harmonizacji prawa w skali międzynarodowej. Wobec diametralnych różnic między prawami poszczególnych państw nie da się bowiem wyznaczyć wspólnego mianownika, na który przystałaby szersza grupa państw. Wydaje się, że z tego powodu trudno będzie wypracować w szerszej grupie państw np. jednolite zasady uznawania skutków zagranicznych procedur, do czego zdaje się prowadzić inicjatywa legislacyjna rozważana przez Haską Konferencję Prawa Prywatnego Międzynarodowego ${ }^{54}$. Celem „Parentage/ Surrogacy Project” prowadzonego od 2010 r. jest przyjęcie regulacji kolizyjnej w przedmiocie pochodzenia dzieci w sytuacjach transgranicznych, w tym dzieci urodzonych przez surogatkę.

Mając na względzie dominację na świecie systemów prawnych, na tle których umowy z surrogate mother są nieważne, łatwiej byłoby uzyskać konsens dla diametralnie odmiennej regulacji, tj. zakazu surrogate motherhood.

\footnotetext{
52 Skarga nr 25358/12. Zob. G. Puppinck, C. la Hougue, Surrogacy. General interest can prevail upon the desire to become parents - about the Paradiso and Campanelli v. Italy Grand Chamber judgment of 24th January 2017, przeł. na jęz. angielski tekstu opublikowanego w „Revue Lamy de Droit Civil RLDC" 2017, No. 146, [on-line:] http://media.aclj.org/pdf/Surrogacy,-general-interetcan-prevail-upon-the-desire-to-become-parents,-Paradiso-and-Campanelli-v.-Italy-2017.pdf 7 VIII 2019.

${ }_{53}$ Zob. Ł. Mirocha, Tzw. macierzyństwo zastępcze (surrogacy, Leihmutterschaft) w bieżacym orzecznictwie Europejskiego Trybunatu Praw Człowieka w Strasburgu, Instytut Wymiaru Sprawiedliwości, Warszawa 2017.

${ }^{54}$ Historia projektu, przebieg i wyniki działań roboczych są przedstawione na stronie internetowej: www.hcch.net/en/projects/legislative-projects/parentage-surrogacy - 7 VIII 2019.
} 


\section{Kwestia tamania zasady pacta sunt servanda przez państwa strony traktatów wobec konwencyjnego zakazu handlu ludźmi (dziećmi)}

Przywołać trzeba tezę, że orzecznictwo trybunałów międzynarodowych dotyczące transgranicznych skutków surrogate motherhood jest obecnie in statu nascendi. $\mathrm{W}$ doktrynie trafnie zauważa się, że na obecnym etapie rozwoju orzecznictwa ETPC omawiana problematyka znajduje się na "przedstandardowym” etapie. Akcentuje się przy tym, że po pierwsze widoczne jest $w$ tym orzecznictwie odwoływanie się bardziej do prawa do prywatności niż prawa do życia rodzinnego; po drugie Trybunał kładzie raczej nacisk na ochronę dzieci pochodzących z surogacji niż rodziców intencyjnych, którzy w dużej mierze byli świadomi ewentualnych trudności prawnych związanych z macierzyństwem zastępczym; po trzecie ETPC uznaje za prawnie relewantny genetyczny związek dziecka z rodzicami intencyjnymi. Ponadto nie można go generalizować ani odnosić do wszystkich, różnorakich w swej istocie, form procedur określonych najczęściej tak samo jako surrogate motherhood ${ }^{55}$.

Nawet pobieżny przegląd powyższych rozwiązań prawnych występujących w niektórych państwach może jednak rodzić wątpliwość co do ich zgodności z zasadami prawa rodzinnego, których ochrona jest przewidziana również $\mathrm{w}$ obrocie międzynarodowym. Kwestia lamania zasady pacta sunt servanda przez te państwa będące stronami traktatów wobec traktatowego zakazu handlu ludźmi (dziećmi) wymaga dokładniejszego zbadania, ale warto zwrócić na nią ogólnie uwagę. W styczniu 2018 r. ukazał się raport specjalnego sprawozdawcy Narodów Zjednoczonych dotyczący sprzedaży i seksualnego wykorzystywania dzieci, w tym dziecięcej prostytucji, pornografii oraz innych przypadków przemocy seksualnej wobec dzieci ${ }^{56}$, w którym wskazano, że obowiązujące aktualnie uregulowania tzw. macierzyństwa zastępczego prowadzą $\mathrm{w}$ istocie do handlu dziećmi.

Karta praw podstawowych Unii Europejskiej ${ }^{57}$ stanowi w art. 5, że „handel ludźmi jest zabroniony". W Europie widoczna staje się polityczna i publicystyczna krytyka obecnej rzeczywistości rozwijającego się biznesu prokreacyjnego.

\footnotetext{
55 Tak Ł. Mirocha, op. cit.

${ }^{56}$ Report of the Special Rapporteur on the sale and sexual exploitation of children, including child prostitution, child pornography and other child sexual abuse material, [on-line:] http://www. un.org/en/ga/search/view_doc.asp?symbol=A/HRC/37/60 - 22 VIII 2018.

${ }_{57}$ Dz.Urz.UE C z 2010 r. Nr 83, s. 389. Zob. R. Kown acki, Ingerencja Karty Praw Podstawowych w zakres realizacji przez państwa czlonkowskie tematów sensytywnych (eutanazja, zwiazki homoseksualne, aborcja) - propagandowy straszak czy realna perspektywa?, [w:] Karta Praw Pod-
} 
Np. Parlament Unii Europejskiej w raporcie na temat praw człowieka i demokracji w świecie w 2014 r. i polityki Unii Europejskiej w tej dziedzinie zdecydowanie krytycznie odniósł się do praktyk tzw. macierzyństwa zastępczego. W ust. 115 raportu potępiono „praktykę macierzyństwa zastępczego, która podważa godność ludzką kobiety, ponieważ jej ciało i funkcje reprodukcyjne wykorzystywane są jako towar”, jak też zauważono, że „praktyka ta, która obejmuje reprodukcyjne wykorzystywanie ciała ludzkiego dla osiągnięcia zysku lub innych korzyści, zwłaszcza w przypadku kobiet znajdujących się w trudnym położeniu w krajach rozwijających się, powinna być zakazana i traktowana jako pilna kwestia w ramach instrumentów z zakresu praw człowieka" ${ }^{58}$. Wydaje się, że w tym pierwszym zdaniu adekwatne byłoby też porównanie do maszyny w fabryce.

Tytułem przykładu można też wskazać Konwencję o ochronie praw człowieka i godności istoty ludzkiej w dziedzinie zastosowania biologii i medycyny ${ }^{59}$, przyjętą przez Komitet Ministrów w 1996 r. W art. 21 przewiduje zakaz osiągania zysku z ciała ludzkiego ${ }^{60}$.

Warto mieć też na względzie rozwiązania prawne stworzone do regulacji adopcji na poziomie międzynarodowym. W europejskiej konwencji o przysposobieniu dzieci z $1967 \mathrm{r}^{61}$ widoczne jest dążenie do zapewnienia dziecku zastępczej matki i ojca. Zgodnie z art. 10 ust. 1 przysposobiony nabywa wobec przysposabiającego wszelkie prawa i obowiązki, jakie ma dziecko pochodzące z małżeństwa w stosunku do swojego ojca lub swojej matki. W pkt 40 raportu wyjaśniającego podkreśla się, że adoptujący wykonuje prawa i obowiązki ojca lub matki zależnie od tego, czy jest mężczyzną, czy kobietą ${ }^{62}$. Natomiast w konwencji haskiej z 1993 r. ${ }^{63}$ założono, że uznawanie skutków przysposobienia dokonanego w trybie konwencyjnym w innych umawiających się państwach, o ile nie jest

stawowych w europejskim i krajowym porzadku prawnym, red. A. Wrób el, Wolters Kluwer Polska, Warszawa 2009, s. 383-396, Monografie.

${ }_{58}$ Rezolucja Parlamentu Europejskiego z dnia 17 grudnia 2015 r. w sprawie rocznego sprawozdania dotyczącego praw człowieka i demokracji na świecie za rok 2014 oraz polityki UE w tym zakresie (2015/2229(INI), [on-line:] www.europarl.europa.eu/doceo/document/TA-8-2015-0470_ PL.html - 8 X 2019.

59 Konwencja o prawach człowieka i biomedycynie z dnia 19 listopada 1996 r. (Europejska Konwencja Bioetyczna).

${ }^{60}$ Zgodnie $\mathrm{z}$ art. 21 ciało ludzkie i jego części nie mogą, same w sobie, stanowić źródła zysku.

${ }^{61}$ Europejska konwencja o przysposobieniu dzieci, sporządzona w Strasburgu dnia 24 kwietnia 1967 r., Dz.U. z 1999 r. Nr 99 poz. 1157.

${ }_{62}$ Zob. European Convention on the Adoption of Children, [on-line:] www.conventions.coe.int/ Treaty/en/Reports/Html/058.htm - 7 VIII 2019.

${ }_{63}$ Konwencja o ochronie dzieci i współpracy w dziedzinie przysposobienia międzynarodowego, sporządzona w Hadze 29.05.1993 r., Dz.U. z 2000 r. Nr 39 poz. 448 ze sprost. 
oczywiście sprzeczne z porządkiem publicznym, następuje po spełnieniu określonych warunków, w tym materialnoprawnych. Należą do nich m.in. wyrażenie dobrowolnej zgody przez matkę po urodzeniu dziecka oraz brak jakiegokolwiek wynagrodzenia za jej udzielenie (tj. brak odpłatności lub innych świadczeń za dziecko).

\section{Uwagi końcowe}

Wprowadzenie w niektórych państwach procedury surrogate motherhood, w tym fikcji prawnych pochodzenia dziecka od osoby lub osób zamawiających, zrodziło fundamentalne kwestie o zasięgu globalnym ${ }^{64}$. Stykają się z nim również trybunały międzynarodowe, w szczególności Europejski Trybunał Praw Człowieka, które mają trudność w ocenie prawnej omawianego zjawiska. Trudność ta jest naturalna, jeżeli przyjęte zostanie założenie skonstruowania w wyroku jakichś rozwiązań merytorycznych. Ponieważ - występujące w danych sprawach - systemy prawne różnią się diametralnie, nie da się w istocie pogodzić „wody z ogniem”. Zaś tzw. złoty środek, rozumiany jako rozwiązanie czerpiące niejako "po trochu” ze zbiegających się systemów prawnych (np. składające się z części ograniczeń pochodzących $\mathrm{z}$ jednego systemu prawnego oraz z części dozwoleń występujących w drugim systemie), w istocie nigdzie nie będzie postrzegane jako rozwiązanie kompromisowe. Paradoksalnie będzie raczej postrzegane jako naruszenie każdego z tych systemów (tj. np. w jednym - z powodu ograniczenia handlowej surogacji, która jest w nim dopuszczana, zaś w drugim - z powodu wyjątkowego dopuszczenia surogacji niekomercyjnej, która nie jest w nim legalna). Stąd poprawniejsze wydaje się podejście orzecznicze polegające na porzuceniu pokusy wykreowania przez trybunał międ zynarodowy jakiegoś globalnego rozwiązania dotyczącego meritum oraz poprzestaniu na formalnym zastrzeżeniu, że z uwagi na biegunowe różnice między państwami jest to logicznie niemożliwe, a sprawy podlegają - co nierzadko występuje odnośnie do innych zakresów przedmiotowych (np. korzystania z broni, posiadania narkotyków, wielożeństwa) - różnym regulacjom lokalnym.

${ }^{64}$ Zob. więcej: A. Wedeł-D omaradzka, Surrogacy - a solution that brings new problems. International organizations and surrogate motherhood, [w:] Fundamental legal problems of surrogate motherhood..., s. 609 i n. 
Ponieważ omówione lokalne rozwiązania prawne mają zastosowanie w praktyce $\mathrm{w}$ różnych nieporównywalnych sytuacjach, również i wątpliwości ich dotyczące mają różny kaliber. Warto zwrócić uwagę, że narastające dylematy aksjologiczne, a za nimi prawnicze, dotyczą sytuacji noszenia przez ciężarną tzw. surogatkę i urodzenia dziecka pochodzącego genetycznie od zamawiających, których dotknęła bezpłodność, a także (dodatkowe zastrzeżenia) odnoszą się do procedur macierzyństwa zastępczego przeprowadzonego celem:

- wyręczenia kobiety, która sama mogłaby zajść w ciążę i urodzić dziecko, ale $\mathrm{z}$ jakichś powodów (np. braku czasu, obaw o wygląd fizyczny) tego nie chce;

- leczenia bezpłodności rozumianego w ten sposób, że tzw. surogatka jest w ciąży i rodzi dla zamawiających dziecko, które nie pochodzi genetycznie od żadnego $\mathrm{z}$ nich (np. komórka jajowa lub nasienie pochodzą z tzw. banku, z którego można dowolnie dobierać cechy dziecka, de facto projektować je bez związku z zamawiającymi i rodzącą);

- dostarczenia dziecka zamawiającym, którzy stanowią konstelacje osobowe, w ramach których in genere dziecko nie może być poczęte (np. pojedynczej osobie, w praktyce mężczyźnie, albo parze osób tej samej płci).

W tym ostatnim wypadku nie można mówić o leczeniu bezpłodności nawet $\mathrm{w}$ szerokim znaczeniu tego słowa, ponieważ z istoty w konstelacjach tych występuje bezpłodność (człowiek nie pochodzi od jednej osoby ani większej liczby osób tej samej płci). Można go natomiast ująć jako przykład realizacji przez dane państwo - za pośrednictwem jego systemu prawnego - swego rodzaju „żądania dostarczenia dziecka". Warto też podkreślić, że niekiedy ewolucja i poszerzanie zakresu zastosowania procedur tzw. macierzyństwa zastępczego nie wynikały z wyraźnej woli ustawodawcy, ale z prawotwórczego (nad)aktywizmu sędziowskiego (np. we Francji i w Ukrainie).

$\mathrm{Na}$ tym tle warto również zauważyć różnice co do kręgu osób, które mogą kontraktowo uzyskać status prawny rodziców dziecka. Mogą być to: genetyczni rodzice dziecka, para składająca się z kobiety i mężczyzny, pary osób tej samej płci (co ma w praktyce doniosłość przede wszystkim dla par składających się $z$ dwóch mężczyzn) bądź pojedyncze osoby (przeważnie kobiety). Odmienności występują również $w$ warunkach po stronie zlecających ( $w$ tym nieudane próby zajścia w ciążę lub urodzenia dziecka, ewentualne wymaganie, by zamawiającymi była para składająca się z kobiety i mężczyzny) oraz kręgu (cech przedmiotowych) zleceniobiorczyń (np. wymaganie określonego młodego wieku oraz wcześniejszego urodzenia zdrowych dzieci, które skutkuje prognozą dobrej jakości „przedmiotu zamówienia”). Różnice występują też w odpłatności za urodzenie zastępcze i możliwości jego komercyjnego organizowania, ponieważ 
teoretycznie w niektórych systemach prawnych zakazane jest zarobkowe działanie pośredniczących agencji. Można mieć jednak wątpliwości, czy zakazy takie w praktyce funkcjonują. Po pierwsze możliwość ich obejścia rodzi się w razie przekazywania agencji lub tzw. surogatce wysokiej (szczególnie po przeliczeniu na lokalną walutę w biednych państwach) sumy pieniężnej, określanej formalnie nie jako zapłata, ale „zwrot kosztów utrzymania i wydatków” zwiększonych w okresie ciąży i połogu. Po drugie zakazy te są w praktyce mało efektywne, jeżeli odnoszą się tylko do procedur dokonywanych na terytorium danego państwa, a jednocześnie uznawane są w nim skutki nabycia dziecka w omawiany sposób za granicą, np. w trakcie krótkich wyjazdów z zachodniej Europy do Azji do państw, w których kwitnie „biznes prokreacyjny”.

Zreferowana wyżej ewolucja rozwiązań prawnych, które zostały wdrożone w niektórych państwach, prowadzi do wniosku, że przyniosły one kolejne (dodatkowe) wątpliwości i zastrzeżenia o naturach aksjologicznej i prawniczej. Na ocenę tych państw mogą mieć ponadto wpływ „techniczne” aspekty doprowadzenia do wystąpienia ciąży u surogatki. Dodatkowe problemy rodzą się wówczas, gdy dziecko nie pochodzi genetycznie od osób zamawiających, a z komórki jajowej lub nasienia osoby czwartej względem umowy o surrogate motherhood (najczęściej anonimowej) albo samej surogatki. W razie wykorzystania materiału z tzw. banku rodzić się mogą ponadto kwestie etyczne dopuszczalności projektowania dziecka (np. płci, rasy, cech fizycznych ${ }^{65}$ ). Natomiast w razie urodzenia przez tzw. surogatkę dziecka, które pochodzi od niej (tzw. surogacja klasyczna, która de facto obecnie w praktyce nie jest popularna, co umyka często opinii publicznej), zasadne jest postawienie pytania, czy omawiana procedura nie obejmuje po prostu sprzedaży i nabycia dziecka oraz stanu cywilnego matki lub ojca, a przy okazji oznacza de facto naruszenie podstawowych zasad systemu adopcji większości państw na świecie, w których istotną rolę odgrywa udział państwa (np. sądu, ośrodka adopcyjnego), m.in. celem ochrony podstawowych krajowych zasad prawa rodzinnego i zapobiegania komercjalizacji.

Na tle obecnego stanu prawnego w niektórych państwach rodzą się więc obecnie nowe - w stosunku do prezentowanych w piśmiennictwie odnoszącym się do rozwiązań pierwotnych sprzed dekady ${ }^{66}$ - fundamentalne i prawnicze kwestie

\footnotetext{
${ }^{65}$ Zob. np. możliwości wyboru pakietów (economy, standard, VIP) oraz określenia przez zamawiającego cech dziecka za pośrednictwem cech tzw. dawcy (kolor oczu, wzrost, wykształcenie) w procedurze zamawianej przez Interenet na: www.biotexcom.com/services - 15 VIII 2018.

${ }^{66}$ Stan normatywny na pocz. XXI w. dokładnie przedstawiają M. Fras, D. Abłażewicz, Reżim prawny macierzyństwa zastępczego na tle porównawczym, „Problemy W spółczesnego Prawa Międzynarodowego, Europejskiego i Porównawczego" 2008, t. 6, s. 31-67.
} 
i problemy. Dotyczą one nie tylko oceny lokalnych systemów, które powyższe rozwiązania przewidują, ale również - a z polskiej perspektywy przede wszystkim - efektywnego funkcjonowania odmiennych krajowych podstawowych zasad prawa w sytuacjach powiązanych (w przeszłości lub obecnie) z kilkoma systemami prawnymi (np. z udziałem własnych obywateli oraz mieszkańców stałych i czasowych, którzy wcześniej przebywali za granicą i podejmowali działania na podstawie prawa obcego), czyli - perspektywy regionalnej i globalnej $j^{67}$. Powstają przy tym fundamentalne wątpliwości co do funkcjonowania uniwersalnej zasady zakazu handlu ludźmi, poprawnego rozumienia przez państwa strony traktatów zasady dobra dziecka, jak też obawy o naruszenie tożsamości dziecka oraz godności ludzkiej kobiet (pochodzących najczęściej z biednych państw) i ich przedmiotowe traktowanie ${ }^{68}$. Obawy obejmują również przyszłe funkcjonowanie systemu adopcji, ponieważ zainteresowanie przysposobieniem sierot może być znacznie mniejsze wobec konkurencyjnej możliwości zamówienia dziecka, w tym jego cech, w drodze zasygnalizowanych wyżej procedur surrogate motherhood ${ }^{69}$.

\section{Streszczenie}

Przedmiotem opracowania są ostatnie zmiany prawa w zakresie surrogate motherhood oraz konsekwencje i problemy z nich wynikające. Zmiany te wskazują w szczególności na diametralne różnice co do dopuszczalności oraz treści surrogate motherhood oraz odmienne tendencje w poszczególnych państwach (albo poszerzania, albo ograniczania lub zakazywania takiego rozwiązania). Na tym tle sygnalizują tė̇ kwestię uznawania skutków zagranicznych procedur i rejestracji stanu cywilnego albo odmowy uznawania, jak te $\dot{z}$ - wątpliwe ich zdaniem - postulaty wykreowania wspólnego unormowania na poziomie międzynarodowym.

Autorzy dochodzą do wniosku, że wprowadzenie w niektórych państwach procedury surrogate motherhood, w tym fikcji prawnych pochodzenia dziecka od osoby lub osób zamawiających, zrodziło fundamentalne kwestie o zasięgu globalnym. Różne dylematy aksjologiczne, a za nimi prawnicze, dotyczą sytuacji noszenia i urodzenia przez ciężarną tzw. surogatkę dziecka pochodzącego genetycznie od

\footnotetext{
${ }^{67}$ Odnośnie do państw członkowskich Rady Europy zob. C. M. de Aguirre, Umowy o międzynarodowe macierzyństwo zastępcze: globalna „Opowieść podręcznej”?, [w:] Fundamentalne prawne problemy surrogate motherhood..., s. $451 \mathrm{i}$ in.

${ }_{68}$ Co celnie podkreśla R. Otowicz, Macierzyństwo zastępcze - wyzwolenie czy zniewolenie?, „Przegląd Powszechny” 1993, nr 2, s. 208.

${ }_{69}$ Co podkreśla K. Bagan-Kurluta, Macierzyństwo zastępcze a adopcje - symbioza czy konkurencja?, „Miscellanea Historico-Iuridica” 2014, t. 13, z. 2, s. 281-297.
} 
zamawiających, których dotknęła bezpłodność, a inne (dodatkowe) dotyczą surrogate motherhood organizowanego celem:

- wyręczenia kobiety, która sama mogłaby zajść w ciążę i urodzić dziecko, ale z jakichś powodów (np. braku czasu, obaw o wygląd fizyczny) tego nie chce;

- leczenia bezpłodności rozumianego w ten sposób, że tzw. surogatka jest w ciąży i rodzi dla zamawiających dziecko, które nie pochodzi genetycznie od obojga z nich (np. komórka jajowa lub nasienie pochodzą z tzw. banku);

- dostarczenia dziecka zamawiającym, którzy stanowią konstelacje osobowe, w ramach których in genere dziecko nie może być poczęte (np. pojedynczej osobie, w tym mężczyźnie, albo parze osób tej samej płci).

Niektóre z tych rozwiązań są de facto przykładami realizacji przez państwo „Żądania dostarczenia dziecka”, które to „żądanie” tym samym uznawane jest przez system prawny za uzasadnione i wiążące. Na tle obecnego stanu prawnego w niektórych państwach rodzą się więc dziś nowe - w stosunku do prezentowanych w piśmiennictwie odnoszącym się do rozwiązań pierwotnych sprzed dekady - fundamentalne i prawnicze kwestie i problemy. Dotyczą one nie tylko oceny systemów prawnych, które powyższe rozwiązania przewidują, ale również - a z polskiej perspektywy przede wszystkim - efektywnego funkcjonowania odmiennych krajowych podstawowych zasad prawa w sytuacjach powiązanych (w przeszłości lub obecnie) z kilkoma systemami prawnymi (np. z udziałem własnych obywateli oraz mieszkańców stałych i czasowych, którzy wcześniej przebywali za granicą i podejmowali działania na podstawie prawa obcego). Powstają przy tym fundamentalne wątpliwości co do funkcjonowania uniwersalnej zasady zakazu handlu ludźmi, poprawnego rozumienia przez państwa strony konwencji ONZ o prawach dziecka z 1989 r. zasady dobra dziecka, jak też obawy o naruszenie tożsamości dziecka oraz godności ludzkiej kobiet (pochodzących najczęściej z biednych państw) i ich przedmiotowe traktowanie. Obawy obejmują również przyszłe funkcjonowanie systemu adopcji, ponieważ zainteresowanie w społeczeństwie przysposobieniem sierot może stać się znacznie mniejsze wobec zaistnienia omówionej konkurencyjnej możliwości pozyskania dziecka (w tym zaprojektowania jego cech fizycznych).

Słowa kluczowe: macierzyństwo zastępcze, urodzenie zastępcze, surogacja, zakaz handlu dziećmi, adopcja międzynarodowa, ujednolicanie prawa w skali międzynarodowej, godność człowieka, macierzyństwo i ojcostwo, umowa o stan cywilny, filiacja, macierzyństwo i ojcostwo

\section{Abstract}

The core of the study are the latest changes in some legal systems in the world in the field of so called surrogate motherhood, as well as the consequences and problems arising from them. In particular, the authors indicate significant differences in the 
admissibility and content of surrogate motherhood and different trends in individual countries (broadening, limiting, or prohibiting such a legal solution). As the consequence, they also signal the issue of recognizing the effects of foreign procedures and registration of civil status or refusal of recognition, as well as - dubious in their opinion - postulates to create a common global regulation at the international level.

The authors come to the conclusion that the introduction of the surrogate motherhood procedure in some states, including legal fictions of the child's origin from the ordering person, gave rise to fundamental issues. Various axiological and legal dilemmas arise. They concern e.g. the situation of being carried by the pregnant socalled surrogate and birth of a child genetically originating from ordering persons affected by infertility, and - with additional dilemmas - other situations:

- ordering by a woman who could get pregnant herself and give birth to a child, but for some reasons (e.g. lack of time, worries about physical appearance) she does not want it;

- the infertility treatment understood in this way that the so-called surrogate is pregnant and gives birth to a child who does not originate genetically from both of them (e.g., egg cell or seed comes from the so-called bank and donors);

- providing the child to personal constellations, in which the child cannot be conceived in genere (e.g. a single man, or a homosexual couple).

Some of these solutions are examples of the state's implementation of a "demand to obtain a child", which is therefore considered legitimate and binding by the state legal system. Against the background of the current legal situation, in some countries new and now fundamental and legal issues and problems are emerging in relation to the ones presented in the literature referring to the original solutions from a decade ago. They concern not only the assessment of legal systems that provide for the above solutions, but also and above all - and from the Polish perspective - effective functioning of different national fundamental legal principles in related situations (in the past or present) with several legal systems (e.g. with a country's citizens as well as permanent and temporary residents who had previously been abroad and took action on the basis of foreign law). At the same time, fundamental doubts arise as to the functioning of the universal principle of the prohibition of trafficking in human beings, correct understanding by the states-parties of the treaties of the principle of the welfare and best interest of the child, as well as concerns about the violation of the child's identity and the dignity of women (most often from poor societies) and their treatment. Concerns also include the future functioning of the adoption system, because the interest in adopting orphans can be significantly less than the competitive ability to order a child via contract (including shaping its future physical characteristics).

Keywords: surrogate motherhood, surrogate birth, surrogacy, prohibition of child trafficking, international adoption, unification of law in international scale, human dignity, maternity and paternity, contract on civil status. 


\section{Bibliografia}

Ad Hoc Committee of Experts on Progress in the Biomedical Sciences - CAHBI, Report on human artificial procreation, [on-line:] https://rm.coe.int/16803113e4 - 24 VII 2018.

de Aguirre C. M., Umowy o międzynarodowe macierzyństwo zastępcze: globalna „Opowieść podręcznej"? [w:] Fundamentalne prawne problemy surrogate motherhood, red. P. Mostowik, Wydawnictwo Instytutu Wymiaru Sprawiedliwości, Warszawa 2019.

Arrêt no. 281 du 19 mars 2014 (13-50.005), Cour de cassation, Première chambre civile, [on-line:] https://www.courdecassation.fr/jurisprudence_2/premiere_chambre_civi le_568/281_19_28731.html-12 IX 2018.

Arrêt no. 371 du 6 avril 2011 (09-17.130), Cour de cassation, Première chambre [Orzeczenie sądu kasacyjnego nr 371 z dnia 6 kwietnia 2011 r., skarga nr 09-17.130], [on-line:] https://www.courdecassation.fr/jurisprudence_2/premiere_chambre_civile _568/371_6_19627.html - 12 IX 2018.

Avis 129, Contribution du Comité consultatif national d'éthique à la révision de la loi de bioéthique 2018-2019, [on-line:] https://www.ccne-ethique.fr/sites/default/files/ avis_129_vf.pdf - 5 IX 2019.

Bagan-Kurluta K., Macierzyństwo zastępcze a adopcje - symbioza czy konkurencja?, „Miscellanea Historico-Iuridica” 2014, t. 13, z. 2, https://doi.org/10.15290/mhi. 2014.13.02.17.

Berger J., Macierzyństwo zastępcze w świetle przepisów prawa Federacji Rosyjskiej, Instytut Wymiaru Sprawiedliwości, Warszawa 2017.

BioTexCom, Center for Human Reproduction, [on-line:] www.biotexcom.com/services - 15 VIII 2018.

Bobrzyńska O., Macierzyństwo zastępcze w prawie francuskim, Instytut Wymiaru Sprawiedliwości, Warszawa 2017, [on-line:] https://www.iws.org.pl/analizy-i-raporty/ra porty\#podstawowe1 - 7 VIII 2019.

Bobrzyńska O., Surrogate motherhood (tzw. urodzenie zastepcze): bieżace tendencje $w$ ujeciu prawnoporównawczym, [w:] Fundamentalne prawne problemy surrogate motherhood, red. P. Mostowik, Wydawnictwo Instytutu Wymiaru Sprawiedliwości, Warszawa 2019.

Brunet L. et al., A Comparative Study on the Regime of Surrogacy in EU Member States, Luxembourg 2013.

Campbell J., The "baby Gammy" case dealing with commercial surrogacy. What happened to baby Pipah? - Farnell \& Anor and Chanbua (2016) FLC 93-700, [on-line:] http://www.wolterskluwercentral.com.au/legal/family-law/baby-gammy-case-deal ing-commercial-surrogacy-happened-baby-pipah-farnell-anor-chanbua-2016-flc93-700/ - 24 VIII 2018.

Comité Consultatif National d'Ethique pour les sciences de la vie et de la santé, Avis du CCNE du 15 juin 2017 sur les demandes sociétales de recours à l'assistance médicale à la procréation (AMP), https://www.ccne-ethique.fr/sites/default/files/publications/ ccne_avis_ndeg126_amp_version-def.pdf. 
European Convention on the Adoption of Children, [on-line:] www.conventions.coe. int/Treaty/en/Reports/Html/058.htm - 7 VIII 2019.

Europejska konwencja o przysposobieniu dzieci, sporządzona w Strasburgu dnia 24 kwietnia 1967 r., Dz.U. z 1999 r. Nr 99 poz. 1157.

Fras M., Abłażewicz D., Reżim prawny macierzyństwa zastępczego na tle porównawczym, „Problemy Współczesnego Prawa Międzynarodowego, Europejskiego i Porównawczego" 2008, Vol. 6.

Fundamental legal issues of surrogate motherhood. Global perspective, ed. P. Mostowik, Wydawnictwo Instytutu Wymiaru Sprawiedliwości, Warsaw 2019.

Fundamentalne problemy prawne surrogate motherhood. Perspektywa krajowa, red. P. Mostowik, Wydawnictwo Instytutu Wymiaru Sprawiedliwości, Warszawa 2019.

Gałązka M., Haberko J., Wybrane zagadnienia macierzyństwa zastępczego, [w:] System prawa medycznego, t. 2: Szczególne świadczenia zdrowotne, red. L. Bosek, C. H. Beck, Instytut Nauk Prawnych PAN, Warszawa 2018.

Haberko J., Dopuszczalność stosowania technik wspomaganego medycznie rozrodu w przypadku zwiazków partnerskich - de lege lata i de lege ferenda, [w:] Zwiazki partnerskie. Debata na temat projektowanych zmian prawnych, red. M. Andrzejewski, Towarzystwo Naukowe Organizacji i Kierownictwa „Dom Organizatora”, Toruń 2013.

Hongladarom S., Surrogacy law in Thailand, [on-line:] https://www.researchgate.net/ publication/322286708_SURROGACY_LAW_IN_THAILAND - 26 VII 2018.

The Human Fertilisation and Embryology Act 2008, [on-line:] http://www.legislation. gov.uk/uksi/2010/987/pdfs/uksi_20100987_en.pdf - 12 IX 2018.

International Surrogacy Arrangements. Legal Regulation at the International Level, ed. K. Trimmings, P. Beaumont, Hart Publishing, Oxford 2013, Studies in Private International Law, Vol. 12.

Jarrett T., Children. Surrogacy - single people and parental orders (UK), [on-line:] https:// researchbriefings.parliament.uk/ResearchBriefing/Summary/CBP-8076 - 15 VIII 2018.

Kasprzyk P., Akty stanu cywilnego w międzynarodowym obrocie prawnym, cz. 1, „Technika i USC" 2005, nr 4; cz. 2, 2006, nr 2.

Kasprzyk P., Pozycja prawna urzędnika stanu cywilnego w Polsce i na Ukrainie, [w:] Z zagadnień prawa rodzinnego i rejestracji stanu cywilnego, red. H. Cioch, P. Kasprzyk, Katolicki Uniwersytet Lubelski Jana Pawła II, Lubelska Szkoła Biznesu Fundacji Rozwoju KUL, Lublin 2007.

Konwencja o ochronie dzieci i współpracy w dziedzinie przysposobienia międzynarodowego, sporządzona w Hadze 29.05.1993 r., Dz.U. z 2000 r. Nr 39 poz. 448 ze sprost.

Konwencja o ochronie praw człowieka i podstawowych wolności sporządzona w Rzymie dnia 4 listopada 1950 r., zmieniona następnie Protokołami nr 3, 5 i 8 oraz uzupełniona Protokołem nr 2, Dz.U. z 1993 r. Nr 61 poz. 284 ze zm.

Konwencja o prawach człowieka i biomedycynie $z$ dnia 19 listopada 1996 r. (Europejska Konwencja Bioetyczna). 
Kownacki R., Ingerencja Karty Praw Podstawowych w zakres realizacji przez państwa członkowskie tematów sensytywnych (eutanazja, zwiazki homoseksualne, aborcja) propagandowy straszak czy realna perspektywa?, [w:] Karta Praw Podstawowych w europejskim i krajowym porzadku prawnym, red. A. Wróbel, Wolters Kluwer Polska, Warszawa 2009, Monografie.

Mikluszka M., Czy można kupić dziecko, czyli problemy prawne i etyczne zwiąane z macierzyństwem zastępczym?, [w:] Współczesne wyzwania bioetyczne, red. L. Bosek, M. Królikowski, C. H. Beck, Warszawa 2010.

Mirocha Ł., Tzw. macierzyństwo zastępcze (surrogacy, Leihmutterschaft) w bieżacym orzecznictwie Europejskiego Trybunału Praw Człowieka w Strasburgu, Instytut Wymiaru Sprawiedliwości, Warszawa 2017.

Mitsutoki Shigeta: 'Baby factory' dad wins paternity rights, [on-line:] https://www.bbc. co.uk/news/world-asia-43123658 - 24 VIII 2018.

Monéger F., La gestation pour autrui, „Revue Internationale de Droit Comparé” 2010, vol. 62, no. 2, https://doi.org/10.3406/ridc.2010.19943.

Morciniec P., Macierzyństwo zastepcze, [w:] Encyklopedia bioetyki, red. A. Muszala, wyd. 2, Polskie Wydawnictwo Encyklopedyczne, Radom 2009.

Mostowik P., Pochodzenie dziecka i odpowiedzialność rodzicielska [w:] System Prawa Prywatnego, t. 20C: Prawo prywatne międzynarodowe, red. M. Pazdan, C. H. Beck, Warszawa 2015.

Mostowik P., Glosa do wyroku Naczelnego Sądu Administracyjnego z dnia 10 października 2018 r. (sygn. akt II OSK 2552/16), „Zeszyty Naukowe Sądownictwa Administracyjnego" 2019, nr 4.

Mostowik P., Kwestia zakresu zastosowania rozporzadzenia UE nr 1191/2016 do zagranicznej rejestracji stanu cywilnego, „Rodzina i Prawo” 2016, nr 37.

Mostowik P., O planach ujednolicenia regut dowodzenia oraz wzajemnej skuteczności rejestracji stanu cywilnego w państwach czlonkowskich Unii Europejskiej (Zielona księga z 14 grudnia 2010 r.), „Metryka. Studia z zakresu prawa osobowego i rejestracji stanu cywilnego" 2011, nr 1.

Mostowik P., Problem obywatelstwa dziecka prawdopodobnie pochodzacego od obywatela polskiego niebędacego mężem surrogate mother. Uwagi aprobujace wyrok NSA z 6.05.2015 r. (sygn. II OSK 2372/13 i II OSK 2419/13), „Problemy Współczesnego Prawa Międzynarodowego, Europejskiego i Porównawczego" 2018, t. 16.

MZT, [on-line:] www.babyrainbow.nl - 15 VIII 2018.

Nesterowicz M., Prawo medyczne, Towarzystwo Naukowe Organizacji i Kierownictwa „Dom Organizatora”, Toruń 2005.

Orzeczenie High Court of Justice z 8.12.2010 r. w sprawie Re L (A minor) [2010] EWHC 3146.

Otowicz R., Macierzyństwo zastępcze - wyzwolenie czy zniewolenie?, „Przegląd Powszechny" 1993, nr 2.

The Parentage / Surrogacy Project, [on-line:] www.hcch.net/en/projects/legislative-pro jects/parentage-surrogacy - 7 VIII 2019. 
Permanent Bureau of the HCCH, The Cross-Border Recognition of Parent-Child Relationship Statuses (Parentage), Including International Surrogacy Arrangements - An Update on the Work of the Hague Conference on Private International Law (HCCH), [w:] Protecting the Rights of Families and Children in a Changing World, eds. B. de Hart, T. Liefaard, T. M. C. Asser Press, Hague 2017, Mededelingen van de Koninklijke Nederlandse Vereniging voor Internationaal Recht, nr 144.

Prawo prywatne międzynarodowe. Komentarz, red. J. Poczobut, Wolters Kluwer, Warszawa 2017, Komentarze LEX.

Preda C. D., Report of 30 November 2015 on the Annual Report on Human Rights and Democracy in the World 2014 and the European Union's policy on the matter, 2015/2229 (INI), [on-line:] http://www.europarl.europa.eu - 7 VIII 2018.

Puppinck G., La Hougue C., Surrogacy. General interest can prevail upon the desire to become parents - about the Paradiso and Campanelli v. Italy Grand Chamber judgment of 24th January 2017, przeł. na jęz. angielski tekstu opublikowa nego w „Revue Lamy de Droit Civil RLDC" 2017, No. 146, [on-line:] http://media.aclj.org/pdf/Surrogacy,general-interet-can-prevail-upon-the-desire-to-become-parents,-Paradiso-andCampanelli-v.-Italy-2017.pdf - 7 VIII 2019.

Przyśliwska-Urbanek E., Macierzyństwo zastępcze z perspektywy prawa Niemiec, Warszawa 2017, [on-line:] https://www.iws.org.pl/analizy-i-raporty/raporty\#podstawowe1 7 VIII 2019.

Przyśliwska-Urbanek E., Macierzyństwo zastępcze z perspektywy prawa Szwajcarii, Instytut Wymiaru Sprawiedliwości, Warszawa 2017, [on-line:] https://www.iws.org.pl/ analizy-i-raporty/raporty\#podstawowe1 - 7 VIII 2019.

Report of the Special Rapporteur on the sale and sexual exploitation of children, including child prostitution, child pornography and other child sexual abuse material, [on-line:] http://www.un.org/en/ga/search/view_doc.asp?symbol=A/HRC/37/60 - 22 VIII 2018.

Rozporządzenie Parlamentu Europejskiego i Rady (UE) 2016/1191 z dnia 6 lipca 2016 r. w sprawie promowania swobodnego przepływu obywateli poprzez uproszczenie wymogów dotyczących przedkładania określonych dokumentów urzędowych w Unii Europejskiej i zmieniające rozporządzenie (UE) nr 1024/2012, Dz.Urz.UE L 200 z 26.07.2016 r.

Safjan M., Prawo wobec ingerencji w naturę ludzkiej prokreacji, Uniwersytet Warszawski, Warszawa 1990.

Skarga nr 65192/11, Mennesson przeciwko Francji.

Skarga nr 65941/11 z 2014 r., Labassee przeciwko Francji, Polskie opracowanie autorstwa M. A. Nowickiego, [on-line:] http://www.hfhr.pl/wp-content/uploads/2015/11/Omowienie_orzeczenia_Mennesson_przeciwko_Francji.pdf - 7 VIII 2019.

Smyczyński T., Stan cywilny [w:] System Prawa Prywatnego, t. 12: Prawo rodzinne i opiekuńcze, red. T. Smyczyński, C. H. Beck, Warszawa 2003.

de Sutter P., Children's rights related to surrogacy, [on-line:] http://assembly.coe.int/nw/ xml/XRef/Xref-XML2HTML-EN.asp?fileid=23015\&lang=en - 24 VII 2018. 
Trimmings K., Beaumont P., Parentage and surrogacy in a European perspective, [w:] European Family Law, Vol. 3: Family law in a European perspective, red. J. M. Scherpe, Edward Elgar Publishing, Cheltenham 2016, https://doi.org/10.4337/9781785363054. 00016.

Wells-Greco M., The status of children arising from inter-country surrogacy arrangements. The past, the present, the future, Eleven International Publishing, Hague 2016.

Wedeł-Domaradzka A., Surrogacy - a solution that brings new problems. International organizations and surrogate motherhood, [w:] Fundamental legal problems of surrogate motherhood. Global perspective, ed. P. Mostowik, Wydawnictwo Instytutu Wymiaru Sprawiedliwości, Warsaw 2019.

Wojewoda M., Transkrypcja aktu urodzenia dziecka, które zostało uznane za granica, „Kwartalnik Prawa Prywatnego" 2017, nr 2.

Wyrok sądu w Nowosybirsku z 2015 r. w sprawie G. Vaśkin przeciwko Nowosibirskiemu Centrum Medycyny Reprodukcyjnej Sp. z o.o.

Zeniv M., Macierzyństwo zastępcze w prawie ukrainskim, Instytut Wymiaru Sprawiedliwości, Warszawa 2017, [on-line:] www.iws.org.pl/analizy-i-raporty/raporty\# podstawowe17 - 7 VIII 2019.

Zielona Księga „Ograniczenie formalności administracyjnych w stosunku do obywateli - swobodny przepływ dokumentów urzędowych i uznawanie skutków powodowanych przez akty stanu cywilnego" COM/2010/0747. 


\section{PraWA CZłOWIEKA}

\section{WOBEC WYZWAŃ WSPÓŁCZESNEGO ŚWIATA}

pod redakcją Agnieszki Czubik, Dominiki Dziwisz, Ewy Szczepankiewicz-Rudzkiej

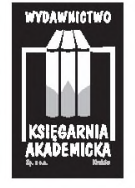

Kraków 
(C) Copyright by individual authors, 2019

Recenzent

prof. dr hab. Barbara Stoczewska

Redakcja

Weronika Werewka

Projekt okładki

Marta Jaszczuk

Photo by Giacomo Ferroni on Unsplash

ISBN 978-83-8138-086-7

Publikacja dofinansowana przez Wydział Studiów Międzynarodowych i Politycznych Uniwersytetu Jagiellońskiego w Krakowie

\section{KSIĘGARNIA AKADEMICKA}

ul. św. Anny 6, 31-008 Kraków

tel./faks: 12 431-27-43, 12 421-13-87

e-mail: akademicka@akademicka.pl

Księgarnia internetowa: www.akademicka.pl 